\title{
Bakü Halı Müzesi’ndeki Çuvallar
}

\section{The Sacks in The Baku Carpet Museum}

\section{Ashkan Rahmani}

Assist. Prof. Dr., Shiraz University Faculty of Art \& Architecture Department of Art

email: rahmani.ashkan@shirazu.ac.ir (DORCID ID: https://orcid.org/0000-0002-6431-7686

\section{Majid Reza Moghanipour}

Assist. Prof. Dr., Shiraz University Faculty of Art \& Architecture Department of Art

email: moghanipour@shirazu.ac.ir (DORCID ID: https://orcid.org/0000-0001-9806-6953

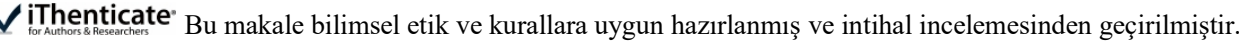 \\ Atıf (APA 6)/To cite this article \\ Rahmani, A., \& Moghanipoor, M. (2020). Bakü Halı Müzesi’ndeki çuvallar. Atatürk Üniversitesi Güzel Sanatlar Enstitüsü Dergisi, 26(44), \\ 73-82. doi: https://doi.org/10.35247/ataunigsed.645017
}

Makale Gönderim Tarihi/Received: 10/11/2019

Makale Kabul Tarihi/Accepted: $13 / 03 / 2020$

Makale Yayın Tarihi/Published: 19/03/2020

Research Article / Araştırma Makalesi

$\ddot{O} z$

Göçebe ve yarı göçebe toplumlarda, eşyaların saklanması için saklama eşyası çok önemlidir. Azerbaycan'ın göçebeleri de diğer göcebeler gibi farklı saklama dokumaları kullanmaktadır. Torba, çanta, heybe, mafraş, çuval, onlardan sayılır. Azerbaycan'da Bakü Halı Müzesine baktığımızda eskiden kalmıs bu tür dokumalar muhafiza edilir. Azerbaycan'da ele geçirilen belgeler ve yapılan alan araştırmasına göre çuvalların, diğer saklama dokumaları gibi yaygın olmadığı görülmüştür. Bu yüzden müzede, Azerbaycan'ın farklı bölgelerine ait sadece 5 parça bulunmaktadır ve bu çalısmada bu parçaların incelemesine odaklanmaktadır. İnceleme sırasında çuvalların renklerine, boyutlarına, kullanılan malzemeye, yaşına, geldiği yere dikkat edilerek, dokuma teknikleri ve desenleri de analiz edilmiștir.

Bu çalışmada Azerbaycan çuvalları "Doğu, Orta ve Batı" olarak sınıflandırılmıştır. Doğuda; Shirvan, Bakü, Kuba, Ortada; Karabağ ve Ganje, Batıda; Kazak yer almaktadır. Araştırmada, Azerbaycan çuvallarının motiflerinin tamamen geometrik olduğu, ayrıca hayvan ve bitki motiflerine de Bakü çuvalında rastlandığı görülmüştür. Desen düzenlemesinin genellikle yatay şeritlere yerleştirildiği ve teknik olarak incelenen çuvalların tamamının havsız teknik ile dokunduğu tespit edilmiștir.

Anahtar kelimeler: Çuval, Azerbaycan, Desen, Renk, Teknik

\begin{abstract}
In nomadic and semi-nomadic societies, storage weaving is very important to put and store of goods. Azerbaijan's nomads as other nomads, use different storage weavings. Bags, small bags, saddlebags, bedding bags, sacks, counted from them. When we look at the Baku Carpet Museum in Azerbaijan, kinds of old weavings are kept and displayed. According to our documents and field research we have obtained in Azerbaijan, sacks are not as common as other storage fabrics, so there are only 5 pieces belonging to different regions of Azerbaijan in the museum and this work will continue on the examination of these pieces. During the examination, weaving techniques and patterns were also analyzed by paying attention to the colors, sizes, materials, age and place of the sacks.

In this study Azerbaijani sacks will be classified as "East, Middle, and West". In the East; Shirvan, Baku, Quba, Middle; Karabag and Ganje, in the West; Kazak are located. Pattern arrangement is usually placed in horizontal panels. The patterns of the Azerbaijani sacks are completely geometric. In addition to these, animal and plant motifs also are seen in Baku sacks. In terms of technique, all of the examined sacks have been woven with flat weave technique.
\end{abstract}

Keywords: Sacks, Azerbaijan, Pattern, Color, Technique

\section{Giriş}

Azerbaycan Güney Kafkasya bölgesinde bir ülkedir ve İran tarafından güney ve batı, doğuda Hazar Denizi, kuzeyden Rusya, batıdan Ermenistan ile sınırlıdır. Eski zamanlardan beri, Azerbaycan seramik, metal, el dokuma gibi çeşitli el sanatlarının merkezi olarak bilinmektedir. Dokuma, Azerbaycan halkının en önemli ortak sanatlarından biridir. Dokuma sanatını bu ülkenin tüm toplumları (Türk, Ermeni, Kürt, Tacik) arasında görmek mümkündür. Çuval dokuması bu el dokumalarından birisi sayılır. Kirkitli dokumalar arasında ticari amaçlı çuvallar üretilmemiştir, dolayısıyla halı ve kilimler gibi desenleri, renkleri ve teknikleri diğer yerlerden etkilenmemiştir.

\section{Yöntem}

Bu çalışma betimsel modele dayalı olarak nitel bir araştırmadır. Azerbaycan çuvalı üzerine ve özellikle Bakü Halı müzesinde saklanan 5 parça çuvalın incelenmesi bu çalışmanın asıl amacıdır. Araştırma yöntemi alan araştırmasına dayanmaktadır. Bu nedenle öncelikle kaynaklar incelenerek, çuvalların teknik, tasarım, renk ve malzeme gibi genel özellikleri ele alınmıştır. Ardından Azerbaycan'ın farklı bölgelerinde ve Bakü Halı Müzesi'nde alan araştırması yapılarak tüm mevcut çuvallar analiz edilmiştir. 


\section{Bulgular ve Yorumlama}

\subsection{Bakü Halı Müzesi}

Müze 1967 yılında halıcı ressam Letif Kerimov’un rehberliği ile kurulmuştur. Müze Letif Kerimov anısına onun adını taşımaktadır ve dünyanın en büyük halı müzesidir. 2014 yılında Neftçiler caddesinde bulunan Stalinist Neoklasik tarzındaki eski müze binasından Hüseynov Caddesindeki müzenin yeni binasına taşınmıştır. Avusturya mimarı Franz Janz tarafından tasarlanan yeni müze binası, katlanmış bir halı şeklindedir. Müzede 10000'in üstünde seramik işleri, metal işi, oya, halı ve diğer el dokumaları bulunmaktadır.

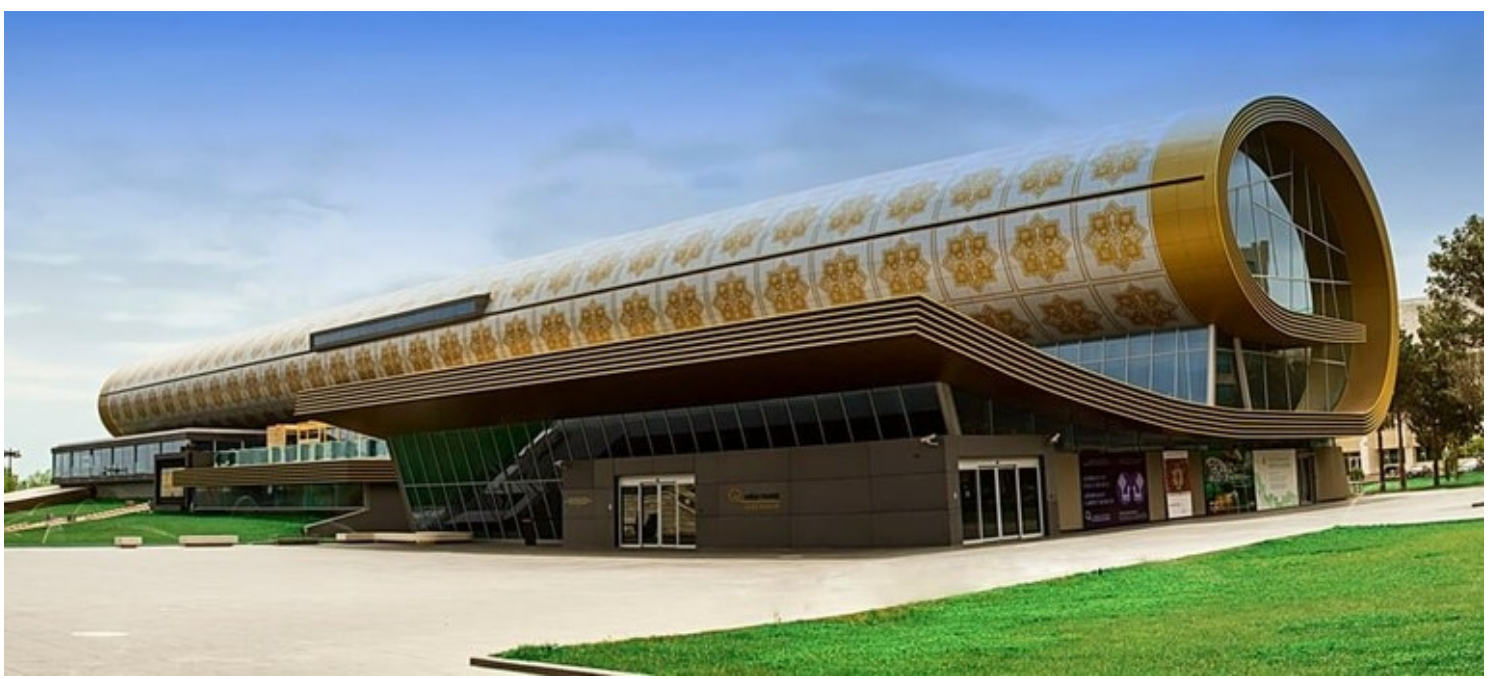

Görsel 1. Bakü Halı Müzesi

\subsection{Cuval Tanıtımı}

Yörükler yılın birkaç ayını göçebelik halinde geçirirler. İlkbahar mevsiminde kışladan yola çıkıp yaylaya doğru giderler, bu göç bazen bir aydan fazla sürebilir. Yaz yaylada üç-dört ay kalırlar, yaz sonunda aynı yoldan daha az yüksek yerlere dönmeye başlarlar. Göç sırasında, eşyalarını hayvanlara yüklerler ve yiyeceklerini, kumaşlarını, kaplarını ve diğer malzemelerini koymak için saklama eşyaya ihtiyaç duyarlar. Tüm göçebe dokuma ürünleri (halı, kilim, çadır, cicim, palas vb.) arasında saklama dokumaları önemli bir yer tutmaktadır. Hurjun (büyük heybe), mafraş, çuval, çanta, torba, tuz torbası, kaşıklık, heybe saklama dokumalarından sayılır. Çuvallar saklama dokuması olarak, göçebe yaşamında önemli bir yere sahiptir. Bunlar tüm göçebe toplumlarda ayrılmaz bir parça olarak görülmektedir. Çuvalın kullanımı bölgeden bölgeye, kültürden kültüre değişilebilir. Anadolu'da çuvallar daha önemli olurken, İran ve Azerbaycan'da mafraşa daha çok önem verilmektedir. Öte yandan, söz konusu iki ülkede, mafraşlardan sonra, çuvallar ve heybeler taşıma aracı olarak ikinci konuma gelmektedir. Çuvallar farklı amaçlar için kullanılır. Kullanılan alana göre malzeme ve desen de seçilir. Bazıları un tutmak için, bazıları ise hayvan yemi ve saman koymak için kullanılır. Alaçuval, giysi ve yatak takımlarını koymak için kullanılır. Anadolu'da eskiden bütün kızların çeyizlerinde en az bir çift çuval bulunmaktaydı ve onları kendisi ya da başka birisine sipariş verip hazırlanırdı ve buna gelin çuvalı denilirdi (Öztürk, 2012, s. 107). Evlendikten sonra, bazıları ekonomik ve sosyal durumlarına bağlı olarak çuval dokuyup eklerler.

Yukarıda da belirtildiği gibi, çuvallar, Azerbaycan, Anadolu ve İran'daki göçebelerde büyük bir önem taşımaktadır ve bu göç sırasında önemli olmasının yanı sıra, çadırlarda da öneme sahiptir. İçerideki insanları soğuk havalardan ve ayrıca insanların dayanabileceği için çadır duvarının dibine yan yana yerleștirilir (Kademoğlu, 1973, s. 26- 27). Yerleşik göçebelerden bazıları hala çuval kullanmakta, bazıları da eskiler gibi eşyalarını (battaniye, kilim, cicim) çuvallarına koymaktadır (Wertime, 1998, s. 15; Powell, 2007, s. 15). Azerbaycan ve diğer ülkelerin göçebelerinde, mafraş ve çuvalların sayısı ailelerinin ekonomik ve sosyal konumlarını göstermektedir. Çuvalların boyutları farklıdır. Uzunluk 60-120 cm arasında ve genişlikleri 55-90 cm arasındadır. Çuvalların bazıları diğer çuvallardan daha desenli ve renklidir. Buna göre, bu çuvalları dokuyan ve kullanan toplumlar, onlara farklı isimler vermektedir. Azerbaycan, Anadolu, Türkmenistan ve İran'ın farklı Türk kökenli toplumlarında, farklı isimler verilmektedir. Çuvalların isimleri teknik, desen, renk ve kullanım alanlarından seçilebilir. Örneğin; Azerbaycan'da, İran'ın Şahseven ve Türkmen toplumları kızıl çuval (kırmızı çuval), Kaşkay toplumunda, kapanma yöntemine göre kilitli çuval veya dokuma tekniğine göre çerh çuvalı denir.

Anadolu'nun bazı bölgelerinde esvab çuvalı, alyanak, yünala çuval, kızllala çuval, karagöz, eğri nakışlı çuval, çamaşır çuvalı, zülüflü, çakmak nakışlı çuval, ismi verilmektedir (Eren, 1976, s. 28; Pekin, 1975; Deniz, 2000; Atlıhan, 1990, s. 58). 


\subsubsection{Desen}

Göçebe yaşam tarzında dokumalar genellikle kadınlar tarafindan dokunur. $\mathrm{Bu}$ nedenle motiflerin isimleri kadınların hayatı, moralleri ve düşünceleri ile ilgilidir. Dokuma tekniğine bağlı olarak basitleştirilen her motif dokumacının inancını, hüznünü ve kederini de yansıtabilir. Ayrıca, tanrıça, ölüm, ölümsüzlük, temizlik, üreme organları, doğanın değişmeyen düzeni ve bu fenomenler her zaman sembolik anlamlar olarak kullanılmıştır (Uğurlu, 1991, s. 78). Çuvallar ticari amaçla dokunmadığı için eski motifler ve desenler düzeni bozulmayıp devam etmektedir. Bu tür dokumalarda, motifler tamamen geometriktir. Sekizgen, Altıgen, eşkenar dörtgen, baklavalar, koç boynuzu, kanca şekilleri farklı kompozisyonlarda kullanılmaktadır. Motifler yatay çizgiler halinde oluşur ve geometrik formlarda şekillendirilir. Çuvalların ön yüzleri renkli ve çeşitli desenlerle dekore edilmiş, arka yüzleri ise basit yatay çizgilerle dokunmuştur. Öte yandan, çuvalın ana motifi toplumun logosunu temsil eder. Aynı zamanda dokumacının becerilerini de gösterir. Bazı bölgelerde göz boncuğu, kurt dişi, deve dişi, kartal pençesi ve püsküller kötülükten korunmak için motifler arasına dikilir.

\subsubsection{Malzeme}

Göçebeler dokumalarında çoğunlukla yün ve bazen keçi kılı kullanırlar. Göçebe toplumun halkı, kendilerinin besledikleri koyun ve keçiden malzeme sağlar. Ancak koyun yünü, görülen ve incelenen örneklerde daha fazla kullanılmıştır. Çünkü Azerbaycan'ın farklı bölgelerinde daha fazla koyun beslenir. Pamuk ipliği aynı zamanda çözgü, atkı ve beyaz desenli ipliklerde de kullanılmaktadır. Ormanlık ve dağlık bölgelerde yaşayan göçebelerin keçi beslediği görülmekte, bu nedenle dokumalarında keçi kılı veya yün karışımı ile çözgü elde edilmektedir. Eski örnekte deve yününün kullanıldığı da gözlemlenmiştir.

\subsubsection{Teknik}

Çuvallar, atkı yüzlü havsız dokuma türlerindendir (Atlıhan, 1990, s. 61). Düz bez dokuma (bezayağı dokuma), havsız atkı yüzlü dokuma, sumak tekniği, takviyeli atkı ile desenleme teknikleri (cicim ve zili tekniği) Azerbaycan çuvallarının dokunması için seçilmiş olan bazı havsız tekniklerden sayılır. Bazı bölgelerde çuvallar, sadece bir teknik ve başka bir bölgede bazen birkaç teknik birlikte uygulanır.

\subsection{Azerbaycan Çuvalları}

Araştırmacılar, Azerbaycan halılarını ve havsız dokumalarını teknik, desen ve renk açısından dört gruba ayırmışlardır; "Quba - Shirvan, Karabag, Tebriz, Ganje - Kazak” (Kerimov 1961, s. 3). Bu nedenle, sonraki araştırmacılar göçebelerin dokumalarını halı grubuna benzer gruplara ayırmışlardır [R. Tagiyeva (kişisel iletişim, 2015)]). Wertime (1998)'a göre, Azerbaycan çuvallarının tanımı "Doğu, Orta, Batı" olarak sınıflandırılabilir.

Azerbaycan'ın tüm bölgelerinde halı, kilim, cicim (çözgü yüzlü), palas, verni, şadda, ladi, çuval, çanta, heybe, mafraş gibi çeşitli el dokumaları farklı boyutlarda eskiden dokunmaktaydı. Ancak Sovyet döneminden sonra el dokumaları yok olmaya başlamıştır ve günümüzde hem göçebelerde ve hem de köylerde çuvallar ve torbalara rastlamak zordur. 2015 yılında araştırmacılar tarafından yapılan alan araştırmasında köylerde ve göçebelerde el dokumalarına fazla rastlanmamıştır. Bu tür dokumalar bulunursa da sadece miras olarak ailelere ulaşmıştır. Şirvan şehri ve köyleri evlerinde halı bulunmaktadır. Azerbaycan'da, İran göçebelerinde olduğu gibi, mafraşlar çuvallardan daha önemlidir. Sonuçta, müzede, özel koleksiyonlarda korunan ve kaynaklarda yayınlanan fazla çuval bulunmamaktadır. Desen olarak mafraşlarda daha zengin olduğu görülmektedir. Çuvallarda, ana motifler dokuma yüzeyinde fazla görünmemektedir. Genelde çuvalın ön yüzünde yatay geniş bir şerit bulunmaktadır. Bu geniş şeritte ana motif çuvalın genişliğine göre üç-beş kez ayarlanır ve tekrarlanır. Bu tür motifler tamamen simetriktir. Şeritlerin genişliği sekiz ile on beş $\mathrm{cm}$ arasındadır ve sayı olarak bu tür düzenlemelerde birdir. Geniş şerit, çuvalın ağız kenarının yaklaşık on cm uzağına dokunmuştur. Genel olarak, çuvalın geniş alanı sade ya da küçük motiflidir. Azerbaycan çuvallarına bakıldığında, desen düzenleme tarzı, Anadolu'nun dikey şeritli çuvalına benzer. Ancak, Anadolu'da, ilk önce başlangıç ve bitiş kısımları birbirine dikilir, daha sonra tabanın kenarları yere konan kısım olarak da dikilir. Azerbaycan'da iki taraf dikilmiştir. Başlangıç ve bitiş ağız olarak kullanılır.

\subsubsection{Doğu Bölgesi Çuvalları}

Şirvan, Talesh, Bakü ve Kuba, Azerbaycan'ın doğusunda yer almaktadır. Bu bölgede Şirvan, Bakü ve Kuba dokumalarda önemli bir yere sahiptir. Doğu bölgesinin en önemli merkezlerinin birisi olan Şirvan, hem hayvancılık ve hem çiftçilik bakımından zengin bir bölgedir. Bu bölgede Şirvan, Aksu, Hacıkabul, Moğan çölü, Şamahı yer almaktadır. Göçebeler (Terekemeler) yerleşik hayata geçmeden önce bu yörede, özellikle Moğan bölgesinde kışlalık yaparlardı. 1873 yılın sonuna kadar Pedar Haji Alim, Marazlı, Arab-Hadim, Kulanı, Moğanlı, Tekla-Haji-Mamed Hosein ve Arab-Bala-Oğlan adlı taifelerin kışlaları Şirvan yöresind yer almaktaydı. Sonralarda Moğan bölgesindeki köyler ve küçük kasabalara yerleştiler (Wertime, 1998, s. 163). Bu yörenin çuval ve mafraşları incelendiği zaman Şahsevenler dokumalarıyla yakın benzerlik göstermektedir. Uzun zaman içerisinde Şirvan, çeşitli dokumalarıyla- Çuval, hurjin, mafraş, at örtüsü- ünlü olmuştur (Tagiyeva, 1999, s. 51). Şirvan bölgesinde "gayık" denilen teknik ile dokunan desene de hemen "gayıklı desen" denir (Wertime, 1998, s. 163). 
Kuba yöresi, hayvan ve bitki yetiştirmek bakımından zengin olduğu için göçebelerin yaşadığı bir bölgedir. Bu yörenin saklama dokumaları sumak tekniği ile dokunur (Wertime, 1998, s. 163). Bu bölge dokumalarının deseni Şirvan grubunun uzantısı söylenebilir. Çünkü incelemesi yapılan dokumaların motifi ve desen düzenlemesi Şirvan grubuna çok yakın bir benzerlik göstermektedir.

Bakü önceden Şirvan bölgesinin küçük bir kasabası durumundadır. Sonraları 18. Yüzyılın yarısından itibaren Kafkas hanlıklarının birisi olmuştur. XIX. Yüzyılın sonuna doğru, Petrol teknolojisi nedeniyle Bakü büyük bir şehre dönüşmüştür (Tagiyeva, 1999, s. 55). Bakü yöresinde halı dışında çeşitli el dokumalarına rastlamak mümkündür. Palas, zili, heybe, çuval, kilim ve mafraş onlardan sayılır. Özellikle zili tekniği Khizy yöresinde dokunur.

Bakü Halı Müzesinde muhafıza edilen ve doğu bölgesine ait olan üç adet çuval bulunmaktadır.
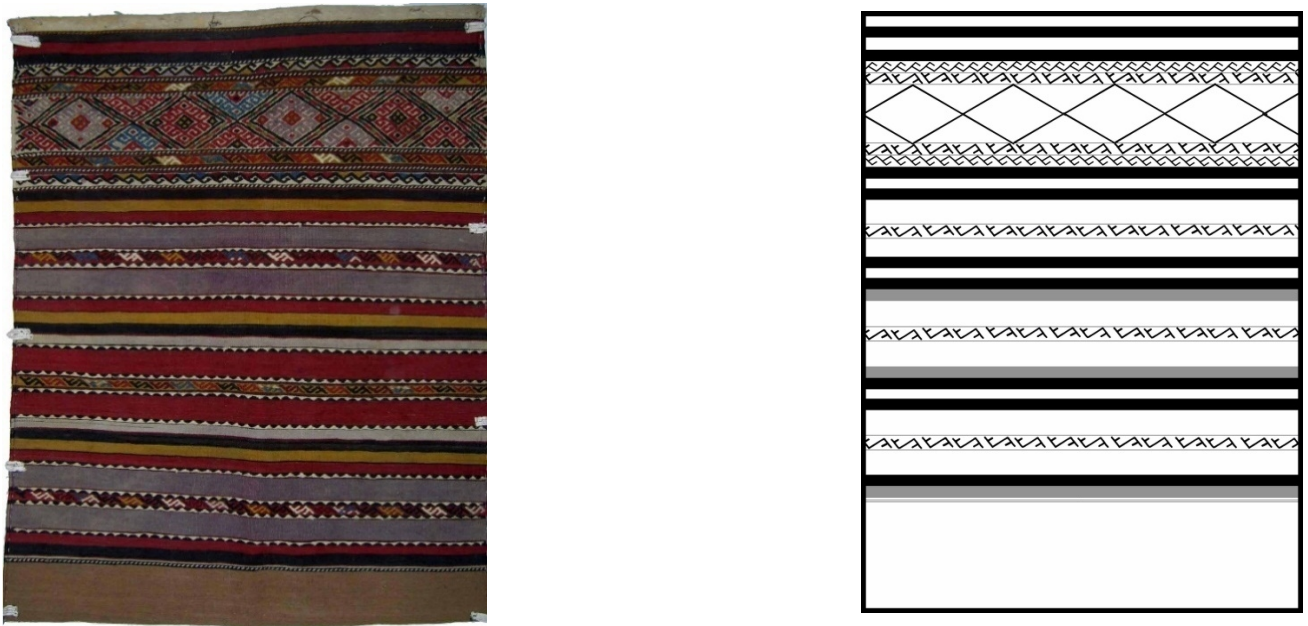

Görsel 2. Şirvan Cuvalı ve yüzey şemas1

\section{Görsel 2 Analizi}

Inv. No.: DDK 2108, Boyut: 80 x 116 cm, Gelen yer: Şirvan, Yaş: 20. yüzyılın başlarında, Saklanan yer: Bakü Halı Müzesi, Malzeme: yün, Renk: sarı, kırmızı, siyah, beyaz, mavi, kahverengi, açık mor

Teknik: takviyeli atkı ile desenleme, atkı yüzlü düz dokuma, sumak tekniği

Desen: Çuvalın ön yüzüne bir sıra geniş şerit yerleştirilmiştir ve geometrik motiflerle doldurulmuştur. Geniş şeritin hemen üst ve alt kısmında dar bir şerit aynı şekilde motifi farklı olarak iki kez tekrarlanmıştır. Dar şerit ve geniş şeritte yer alan motif, hemen İran Türklerinde (Kaşkay, Şahseven, Türkmen) dokumalarında ve hem de Batı Anadolu çuvallarında ortaya çıkmaktadır. İkinci dar şeritte dokunan motif, Akdeniz bölgesinde ve Batı Anadolu çuvallarında görülür.

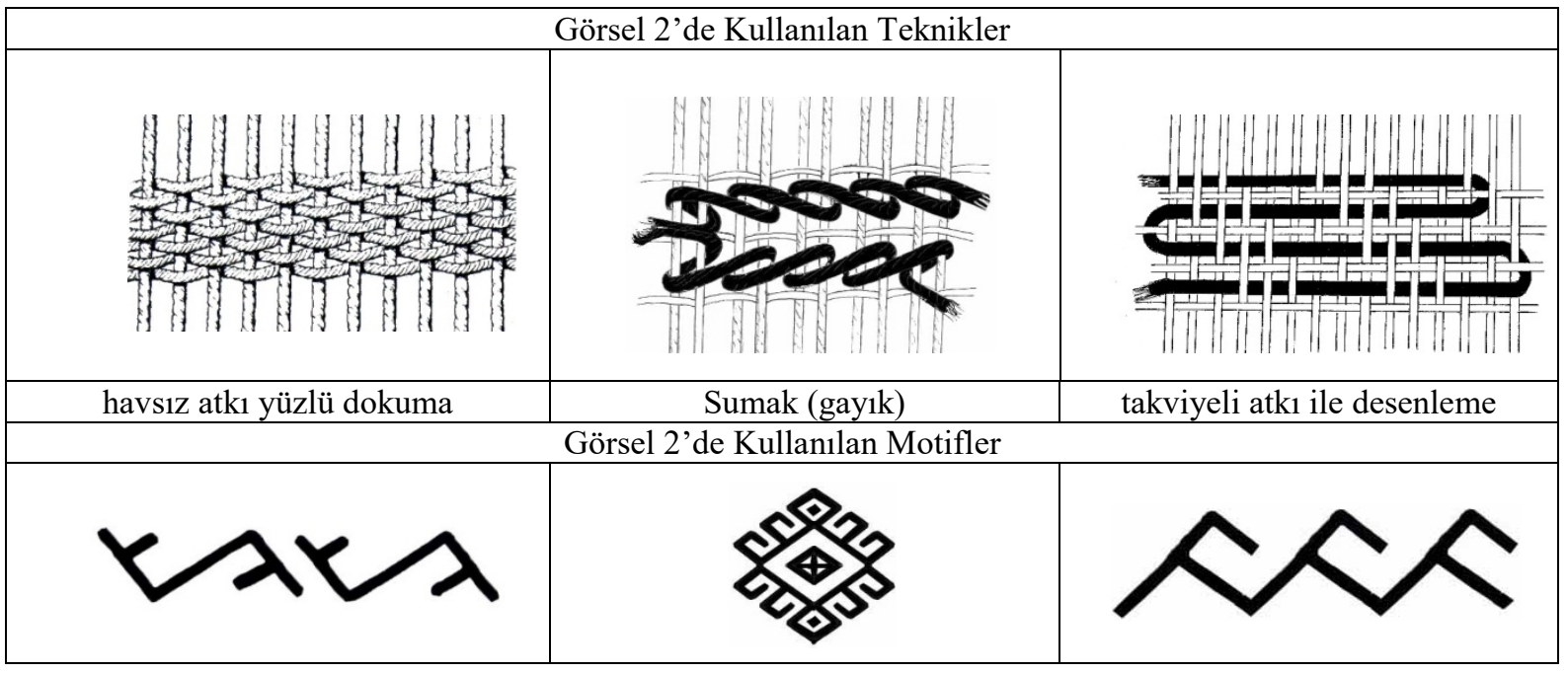



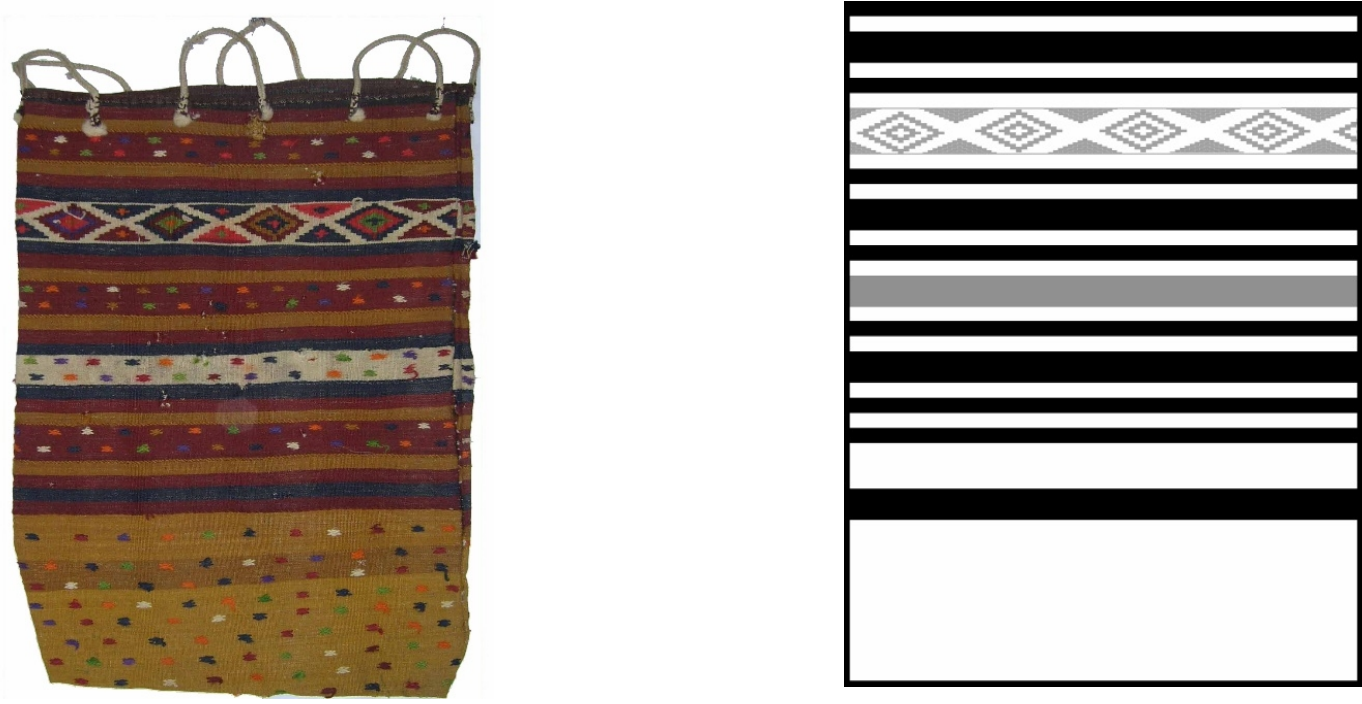

Görsel 3. Şirvan Çuvalı ve yüzey şeması

\section{Görsel 3 Analizi}

Inv. No.: DDK 2108, Boyut: 64 x 93 cm, Gelen yer: Şirvan, Yaş: 20. yüzyılın başlarında, Saklanan yer: Bakü Halı Müzesi, Malzeme: yün, Renk: sarı, kırmızı, beyaz, koyu mavi, kahverengi, turuncu

Teknik: ilikli kilim

Desen: Çuvalın ön ve arka yüzleri aynı düzenden oluşur. Çuvalın üst yarısında iki geniş şerit vardır. Alt şerit desensiz ve üst şerit baklava ve üçgen motifleri içerir. Bu iki geniş şeritin zemini beyaz rankle diğer desensiz şeritlerden ayrılmıştır. Çuvalın alt kısmından başka, diğer kısımlar desensiz dar bir şeritlere bölünmüştür. Desensiz kısımlar püsküllerle süslenmiştir ve ağız iki cm içe doğru dikilmiştir. Çuval dikilmemiş halde muhafıza edilir. Taşımak için çuvalın ağzına altı halka dikilmiştir.

\begin{tabular}{|l|l|}
\hline & Görsel 3'de Kullanılan Teknikler \\
\hline havsız atk1 yüzlü dokuma & \\
\hline & Görsel 3'de Kullanılan Motif \\
\hline
\end{tabular}



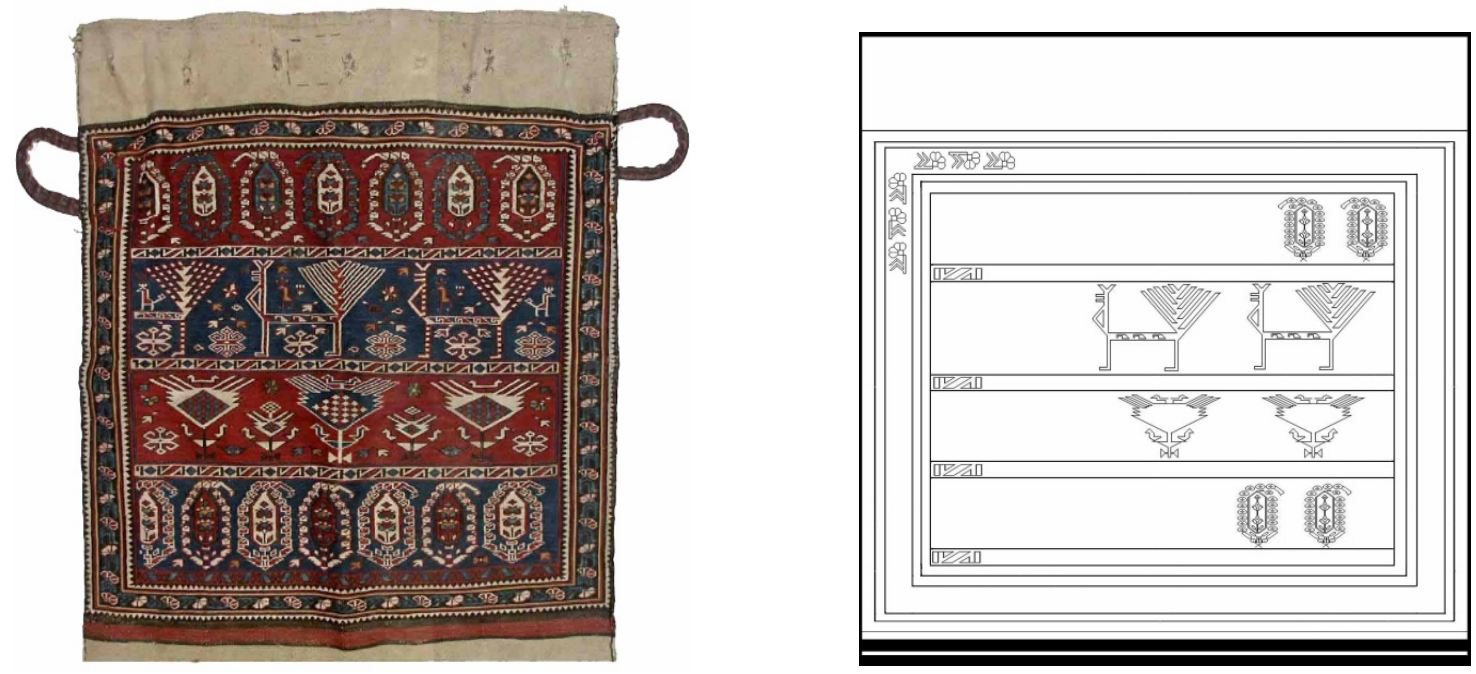

Görsel 4. Bakü Çuvalı ve yüzey şeması

\section{Görsel 4 Analizi}

Inv. No.: DDK 2467, Boyut: 75 x 81 cm, Gelen yer: Bakü, Yaş: 19. Yüzyıl, Saklanan yer: Bakü Halı Müzesi, Malzeme: yün, Renk: beyaz, kırmızı, yeşil, koyu mavi, siyah, sarı

Teknik: atkı yüzlü düz dokuma, sumak tekniği

Desen: $\mathrm{Bu}$ çuval hemen kare şeklinde olan bir dokuma türüdür ve desen olarak daha çok halı desenine benzemektedir. Bördürde kullanılan çiçekler motifi, Kuba'nın halısının ince bördürlerinde yer almaktadır. Zeminde kullanılan tavus kuşu ayrıca Bakü'nün küçük bir kasabası Khizy olarak zilisinde kullanılması görülmektedir. Zeminde boteh adı verilen motif İran'ın birçok bölgesinin dokumalarında, özellikle Azerbaycan bölgesinde yaşayan Şahseven yörükleri dokumaları ve Bijar Şehri kilimlerinde bu biçimde kullanışır. Çuvalın taşınması için iki adet kulp kenara dikilmiştir.

Örnek 3'de Kullanılan Teknikler




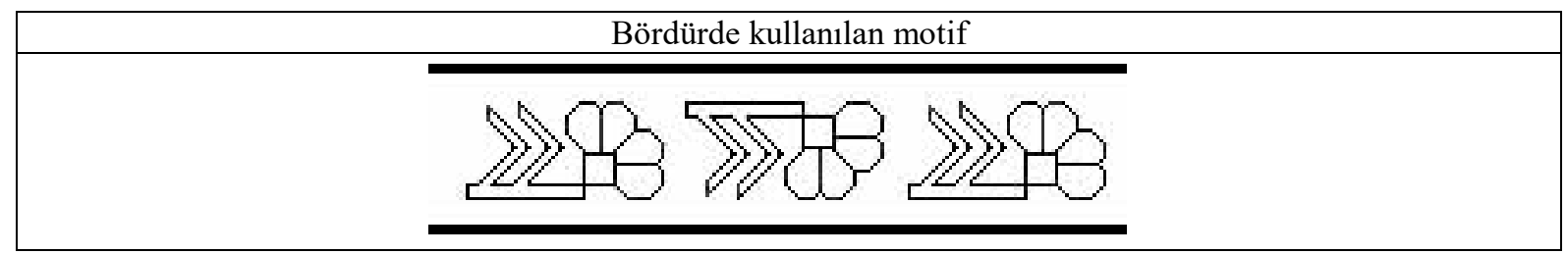

\subsubsection{Orta Bölgesi Çuvalları}

Karabağ’’n çölleri, çiftlik için uygun bir yere sahiptir. Bu bölgenin dağları da hayvancılıkla uğraşan göçebelerin yaşadığı uygun bir yöre sayılır. Son zamanlara kadar Karabağ yöresinin nüfusunun yarısının göçebe olduğu bilinmektedir. Şirvan yöresinde kışı geçiren göçebelerin bir kısmının yayla olarak Karabağ dağlarına çıktığı bilinmektedir. XIX. Yüzyılın sonunda çoğu yerleşik hayata geçmişlerdir. Wertim'in araştırmasına göre, Azerbaycan'ın mafraşının çoğu Karabağ'a ait (Wertime, 1998, s. 172). Bu nedenle Karabağ'da çuvalların dokunmuş olduğu tahmin edilmektedir. Bu yörede çeşitli düz dokumalar da dokunmaktadır; Şadda, verni, palas, kilim, çözgü yüzlü cicim onlardan sayılır. Kerimov, araştırmalarında elde ettiği kaynaklara göre eski zamanlarda Karabağ, Barda ve sonra Şuşa bölgesinde bütün kadınlar dokumayla uğraşmaktadır (Kerimov, 1985, s. 228). Araştırmada bu bölgeye ait olan çuvallara yöçnelik hem alan araştırmasında, hem yayınlarda, hem de Bakü Halı Müzesinde örnek bulunamamıştır. Karabağ bölgesinin dokuma merkezleri iki gruba bölünür. 1) Dağlık bölgeler: Daşbulag, Dovşanlı, Muradhanlı, Gasımuşă̆ı, Gubadlı, Gogaz Bağırbeyli bu bölgede yer alır. 2) Çöller: Jabrayıl, Agdam, Barda, Fizulu. İki grup dışında Nahcivan da Karabağ bölgesinde yer almaktadır.

\subsubsection{Batı Bölgesi Çuvlları}

Kazak bölgesi Azerbaycan'ın batısında yer alır. Bu bölgenin doğu ve güney doğusunda Gence bölgesi, güneyinde Ermenistan, Kuzeyi ise Gürcistan ülkesi yer almaktadır. Kazak bölgesinde Türkler ve Ermeniler yaşamaktadır. XIX. yüzyılın sonunda, Kazak bölgesinin nüfusu \%57 Türk ve \%40 Ermeni oluşturmuştur (Wertime, 1998, s. 204). Kazak bölgesi dokumaları iki gruba bölünür; 1) Kazak yöresi 2) Borçalı yöresi: günümüzde bu bölge, Gürcistan ülkesinde yer almaktadır; ancak, Kazak yöresi dokumalarının özelliğini yansıtmaktadır (Kerimov, 1985, s. 229). Kazak bölgesinde verni, zili, mafraş, şadda, namazlık ve at örtüsü dokumaları yaygındır (Tagiyeva, 1999, s. 5-7). Bu bölge mafraş ve çuvallarının motifi diğer bölgelerde göründüğü gibi yoğun bir kısmı çengeller, koçboynuzu, baklavalardan oluşmaktadır.
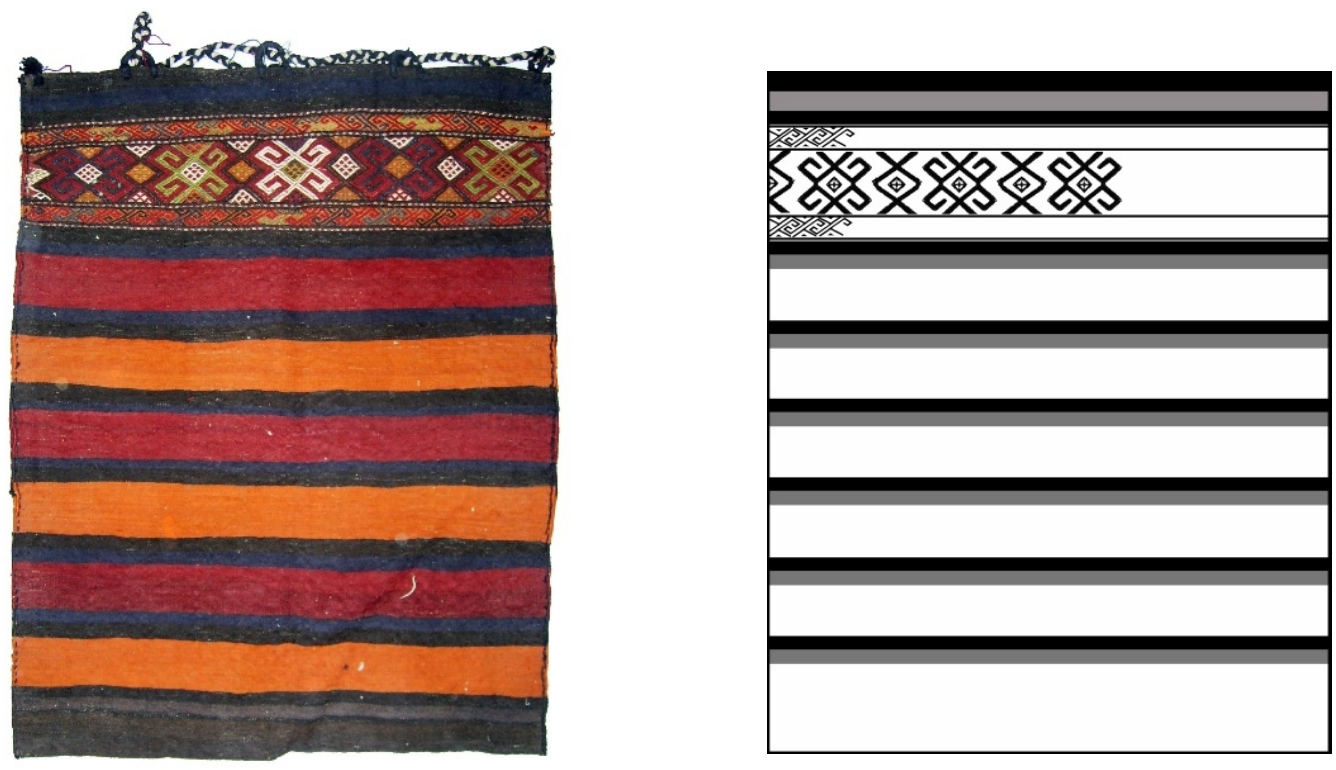

Görsel 5. Kazak Çuvalı ve yüzey şeması

\section{Görsel 5 Analizi}

Inv. No.: DDK 8586, Boyut: 80 x $105 \mathrm{~cm}$, Gelen yer: Kazak, Yaş: 20. Yüzyllın ikinci çeyreği, Saklanan yer: Bakü Halı Müzesi, Malzeme: yün, Renk: turuncu, kırmızı, siyah, beyaz, mavi, yeşil

Teknik: takviyeli atkı ile desenleme, atkı yüzlü düz dokuma 
Desen: Çuvalın ön yüzünde $10 \mathrm{~cm}$ ağza yakın bir sıra geniş şerit yerleştirilmiştir ve geometrik motiflerle doldurulmuştur. Geniş şeritin hemen üst ve alt kısmında dar şerit yerleştirilmiştir. Geniş şerite yerleştirilen motif İran Türklerinin (Kaşkay, Şahseven, Türkmen) dokumalarında ve Doğu Anadolu'da özellikle Kürt çuvallarında ortaya çıkmaktadır. Desensiz kısım da desenli kısıma benzer dar ve geniş şeritlere bölünmüştür.

\begin{tabular}{|c|c|}
\hline Görsel 5'de Kullanilan Teknikler \\
\hline havsız atk1 yüzlü dokuma & Görsel 5'de Kullanilan Motifler \\
\hline
\end{tabular}
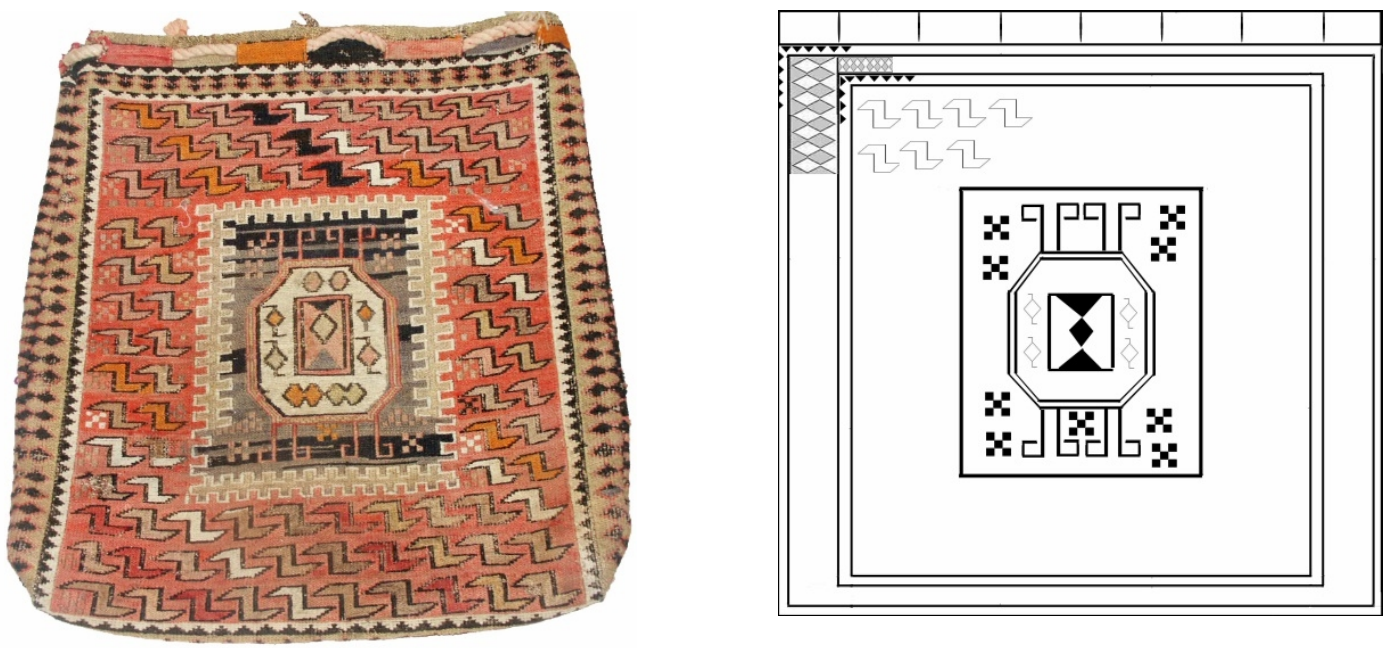

Görsel 6. Kazak Çuvalı ve yüzey şeması

\section{Görsel 6 Analizi}

Inv. No.: DDK 8250, Boyut: 51 x 55 cm, Gelen yer: Kazak, Yaş: 19. Yüzyılın sonu, Saklanan yer: Bakü Halı Müzesi, Malzeme: yün, Renk: turuncu, kırmızı, siyah, beyaz, siyah, açık kahverengi

Teknik: ilikli kilim

Desen: Çok nadir madalyonlu küçük bir çuval olarak görülür. Çuvalın ön tarafı üç bölüme ayrılmıştır; madalyon, zemin ve bordür. Bordürde kullanılan motif genellikle halıların ve özellikle İran halılarının bordüründe görülür. Kaşkay toplumu kilimlerinde müdahil adı verilen ve sık sık görülen bir motiftir. Zeminde kullanılan "S" şekilli motif, en sevilen ve yaygın motiflerden birisi olarak dokumalarda görülür. Farklı tekniklerde uygulanan bu motif, teknikler ve yöreye göre farklı biçimler ve isimler alır. Şahsevenlerde "Aptalburun" denilen bu motifin bir biçimine, Kaşkaylarda "ağaceri” denilir. Türkmenistan, Azerbaycan ve Anadolu dokumalarında sürekli rastlanır (Azadi ve Andrews, 1985, s. 37). Araştırmacılara göre "S" biçimi yılan ve ejderha şeklini andıran bir motiftir (Landreau ve Pickering, 1969, s. 13; Tanavoli, 1985, s. 46). Diğer görüşler ise ejderha ve yllan bu motifin bir kaynağı olduğu halde başka kaynakların olması da muhtemeldir. Parham (1991)'a göre yuvarlak çizgiler XII. Yüzyıldan sonra Çin minyatürlerinden İran minyatürlerine geçmiştir. Bu biçim daha çok eski tarihe dayanabilir. Sonralarda deforma olarak bu biçimi almıştır. M.Ö. 3000'e ait İran'da Giyan tepesinde bulunan çanak çömlek üzerinde resim edilen antilop motifi "S" şeklinin kaynağı olabilir (s. 361). Dikdörtgen şeklindeki madalyon bu çuvalın içinde yaygın olmayan ve eşsiz bir formdur. Bu çuvalın ağzı, İran çuvallarına benzer, ancak kapatılması İran'ınki ile farklıdır. 


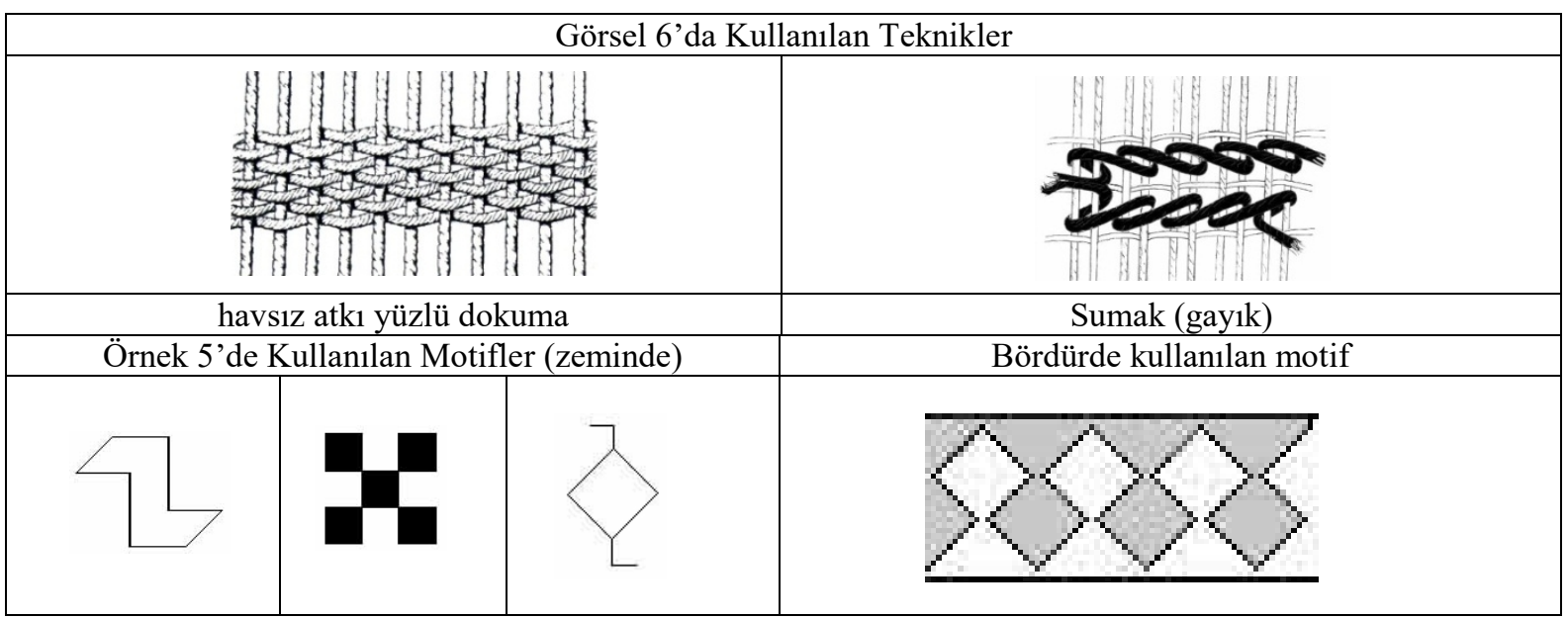

\section{Sonuç}

Çalışma sonucunda, geleneksel dokumada, tekniğe ve renge ek olarak, desenler ve tasarım kompozisyonunun oldukça değerli olduğu tespit edilmiştir. Dokuyucular, akıllarını rahatça tutabilecek şekilde motifleri biçimlendirirler. Bu nedenle, çuval motiflerinin geometrik olduğu görülmektedir. Geometrik olmanın bir diğer nedeni de teknik gerekliliktir. Çuvallarda kullanılan ve tercih edilen dokuma tekniği havsız tekniktir ve bu özellikler incelen örneklerde rastlanmıştır.

Geometrik yapıda simetrik motifler $(1 / 2,1 / 4, v b$.) tercih edilmiştir. Üçgen, eşkenar dörtgen, baklava, altıgen, sekizgen ve kanca formları motiflerde en yaygın formlardır. Bakü çuvallarında basitleştirilmiş kuş, hayvan figürleri ve bitkisel motifler de göze çarpmaktadır. Genellikle geniş şeritlerde yer alan motifler ana motif olarak kabul edilir. Dar şeritlere yerleştirilen motifler, bir şekilde ana motifi tamamlayıcı niteliktedir. Çuvallardaki yatay şerit düzenlemeleri, bu çuvalların en yaygın bileşimidir.

Göçebe toplumlarda, bütün çuval ve diğer dokuma malzemesi ailenin ürünüdür. Koyun ve keçi kırkması, bu tür toplumlardaki ev erkeğinin görevidir. Kadınlar yün yıkar, tarar, eğirir, döndürür ve boyar. Bu gelenek, Orta Asya, İran, Azerbaycan ve Anadolu göçebeleri arasında yaygındır.

Azerbaycan'ın göçebeleri tarafından dokunan çuvalların teknik, renk ve bazı motifler açısından aynı özelliklere sahip olduğu görülmektedir. Elyafın taranması ve didilmesi, eğirme, büküm ve el aletlerinin dizgi yöntemleri Azerbaycan'ın tüm bölgelerinde aynıdır.

Dikey dokuma tezgâhı çoğunlukla Azerbaycan'da görülmektedir. Göçebe dokumaların ayırt edici özelliklerinden biri, desen ipliklerin doğal boyalarla boyanmasıdır. Azerbaycan'da boyama yöntemleri neredeyse aynıdır. Bununla birlikte, son zamanlara ait dokumalar arasında sentetik boyama da görülmektedir.

Sonuçta sayı olarak çuvallar diğer saklama dokumalarına göre Azerbaycan' da oldukça az dokunmuştur. Araştırma sonucubda ulaşılan yayınlardan ve müzelerde muhafıza edilen, özel koleksiyonlarda saklanan ve alan araştırması yapılan bölgelerden çuvallara rastlanmadığı görülmüştür.

\section{Kaynakça}

Atlıhan, Ş. (1990). Ayvacık bölgesinde Alaçuvallar. Kültür ve Sanat Dergisi, 5, 56-63.

Azadi, S., \& Andrews P. A. (1985). Mafrash, woven transport packs as an art form among the Shahsevan and other Nomads in Persian. Berlin: Dietrich Reimer Verlag.

Deniz, B. (2000). Türk dünyasında halı ve düz dokuma yaygıları. Ankara: Atatürk Kültür Merkezi Yayını.

Eren, N. (1976). Yörük çuvallar1. Türkiyemiz Dergisi, 18, 27-32.

Kademoğlu, O. (1975). Anamas yaylalarında. Türkiyemiz Dergisi, 10, 26-27.

Kerimov, L. (1961). Azerbaydjanskiy kover. vol.1. Baku- Leningrad.

Kerimov, L. (1985). Azerbaijan carpet. Baku. Jazychy.

Landreau, A. N., \& Pickering W. R. (1969). From Bosphorus to Samarkand flat-woven rugs. Washington, D. C.: The Textile Museume.

Öztürk, P. F. (2012). Manavgat ilçesi ve köylerindeki düz dokumalar. Arış Dergisi, 17, 102-111. 
Parham C. (1991). Destbaft haye Aşayeri ve Roostayi Fars (Tribal and Village Rugs from Fars), Vol. 2, Tehran: Amir Kabir.

Pekin, E. (1975).Yörük çuvalları. Sanat Dünyamız, 5, 14-17.

Powell, J. (2007). From generation to generation: Anatolian nomad storage sacks: Giving back the colours. İstanbul: Sadberk Hanım Müzesi.

Tagiyeva, R. (1999). Azerbaijan carpet. Baku: Scientific Publication.

Tanavoli, P. (1985). Shahsavan, Iranian rugs and textiles. New York: Rizzoli International Publication.

Uğurlu, A. (1991). Anadolu dökümalarında motif felsefesi. Tekstil ve Mühendis Dergisi. 26, 76-82.

Wertime, J. T. (1998). Sumak bags of northwest Persia and Transcaucasia. London: Laurence King.

\section{Görsel Kaynakçası}

Görsel 1. Bakü Halı Müzesi. (2017). Kaynak: Ashkan Rahmani kişisel arşivi

Görsel 2. Şirvan Cuvalı ve yüzey şeması. (t.y.). Kaynak: Bakü Halı Müzesi arşivi

Görsel 3. Şirvan Cuvalı ve yüzey şeması. (t.y.). Kaynak: Bakü Halı Müzesi arşivi

Görsel 4. Bakü Halı Müzesi. (2017). Kaynak: Ashkan Rahmani kişisel arşivi

Görsel 5. Bakü Halı Müzesi. (2017). Kaynak: Ashkan Rahmani kişisel arşivi

Görsel 6. Bakü Halı Müzesi. (2017). Kaynak: Ashkan Rahmani kişisel arşivi

\section{Kaynak Kişiler}

Tagiyeva, R. (2015). Bakü Halı Müzesi Müdürü. “Azerbaycan çuvalları” konulu görüşme. Bakü. 